\title{
Meeting the Needs of Malaysian Mathematically Talented Students by An Enrichment Program: A Module For Primary School Students
}

\author{
Faieza Samat*, Eddie Shahril Ismail \\ Universiti Kebangsaan Malaysia
}

School holiday enrichment program annually organized by PERMATA pintar National Gifted Centre was to uncover hidden talents in science and mathematics. Students in this program were grouped into different courses. In order to run the Introduction to Cryptology course for primary school students, a new module has been developed. This module has been implemented for the first time during the school holiday program in December 2017. Thus, this study aimed at determining mathematics achievement of 34 Malaysian primary school students in Introduction to Cryptology course. An examination consisting of a set of questions on mathematical concepts was being given to each of the students during the final day of the program. Student scores were being evaluated to assess their achievement. Findings indicate that $73.6 \%$ of students scored between 80 and 100 in the examination. Students have good achievement in the concept of integers but they have deficiency in the concept of matrices. Hence, it can be concluded that the students indeed have special ability in doing mathematics. Since matrices were new to Malaysian primary school students, thus interesting activities relating to matrices will be included in the module to intensify students' motivation in mathematics. 


\section{INTRODUCTION}

Students exhibiting mathematical promise or mathematically talented students understand mathematics differently than other students. Lester and Schroeder Tsui (2017) listed twelve cognitive characteristics of mathematically talented students. One of the attributes was the ability to reverse the reasoning process (switch from a direct to a reverse train of thought) which talented students performed with relative ease. Thus, the students' thinking was not only different, it resembles the way that professional mathematicians work with the only difference is in the degree of sophistication Sriraman (2004).

In order to address the learning needs of mathematically talented students', experts in gifted education suggested accelerative programs, enrichment programs and modified curriculum. Enrichment programs are recommended for moderately talented students as the programs give students motivation. Tsui (2017) indicates that when pupils were motivated to carry out a complex and in-depth investigation, they often sought new and more advanced knowledge. McAllister and Plourde (2008) designed an inquiry-based enrichment program and discovered that using higher-level math concepts engaged students and kept them excited about learning. Besides that, Gavin et al. (2009) developed and field tested advanced curriculum for mathematically promising elementary students. They found that the curriculum which focused on disciplinary thinking Tomlinson et al. (2002) had positively affected the students' achievement.

School holiday enrichment program organized by PERMATApintar National Gifted Centre was a program to uncover hidden talents in science and mathematics. Each course in the program was handled by course instructors and teaching assistants. One of the courses offered in this program was Introduction to Cryptology course. Students who attend this course were from different schools in Malaysia and had passed UKM 1 and UKM 2 identification tests. They have already mathematical knowledge learned at primary school level. In this Introduction to Cryptology course, students were introduced to the higher level of mathematical concepts behind cryptology which were integers and matrices. Thus, in this study we would like to determine whether or not students have mastered each concept in the integers and matrices.

\section{METHODOLOGY}

This study was carried out to 34 12-year old students attending Introduction to Cryptology course in the school holiday

\section{REFERENCES}

Gavin, M. K., Casa, T. M., Adelson, J. L., Carroll, S. R., and Sheffield, L. J. (2009). The Impact of Advanced Curriculum on the Achievement of Mathematically Promising Elementary Students. Gifted Child Quarterly 53, 188-202. doi: $10.1177 / 0016986209334964$

McAllister, B. A. and Plourde, L. A. (2008). Enrichment curriculum: Essential for mathematically gifted students. Education 129, 40-49.

Sriraman, B. (2004). Gifted Ninth Graders' Notions of Proof: Investigating Parallels in Approaches of Mathematically Gifted Students and Professional Mathematicians. Journal for the Education of the Gifted 27, 267-292. doi: 10.4219/jeg-2004317. enrichment program. During this 3-week program, students were taught some basic mathematical concepts and elements of cryptology based on a module. After learning all mathematical concepts, students were being given a set of questions to assess their achievement in mathematics. Table $\mathbf{1}$ displays the distribution of mathematical concepts covered in each questions.

\section{RESULTS AND DISCUSSION}

Student scores in the examination were tabulated in Table 2 .

From the above table, most students scored 80 - 100 while only one student scored $45-49$ in the examination. This shows that $73.6 \%$ students have mastered all mathematical concept learned in this course. Scores for each questions in the examination were displayed in Table 3 to determine scores for each mathematical concept using the following formula.

$\frac{\text { students mark in the related questions }}{\text { total marks for that questions }}$ 100\%

rom Table 3 , all students scored $50-100$ on the concept of integers which shows that this concept dominates the matrices. For the concept of integers, 2 students have difficulty in solving the division problems while 2 students have difficulty in solving operation on integer modulo $n$ problems. Meanwhile, for the concept of matrices, 11 students scored $0-34$ in finding the inverse of a matrix, 2 students scored $0-34$ in subtracting matrices, 1 student scored $0-34$ in adding matrices modulo $n$ and 3 students scored $0-34$ in multiplying matrices.

From Table 3, all students scored $50-100$ on the concept of integers which shows that this concept dominates the matrices. For the concept of integers, 2 students have difficulty in solving the division problems while 2 students have difficulty in solving operation on integer modulo $n$ problems. Meanwhile, for the concept of matrices, 11 students scored $0-34$ in finding the inverse of a matrix, 2 students scored $0-34$ in subtracting matrices, 1 student scored $0-34$ in adding matrices modulo $n$ and 3 students scored $0-34$ in multiplying matrices.

\section{CONCLUSION}

From the results, it is observed that students have mastered the concept of integers but were deficient in the concept of matrices. Integers were the extension of natural numbers hence the concept can be easily understood by the students. Matrices were new to students, thus interesting activities relating to matrices should be included in the module to intensify students' motivation in mathematics.
Tomlinson, C. A., Kaplan, S. N., Renzulli, J. S., Purcell, J. H., Leppien, J. H., Burns, D. E., et al. (2002). The parallel curriculum: A design to develop high potential and challenge high-ability learners (Sage Publications Company: Corwin Press), $1-289$.

Tsui, B. P. H. (2017). How to address the needs of mathematically gifted students? Department of Curriculum, Teaching and Learning Ontario Institute for Studies in Education of the University of Toronto, 1-69.

Conflict of Interest Statement: The authors declare that the research was conducted in the absence of any commercial or financial relationships that could be construed as a potential conflict of interest. 
TABLE 1 | Distribution of questions on mathematical concepts

\begin{tabular}{|c|c|c|}
\hline Question number & \multicolumn{2}{|c|}{ Mathematical concept } \\
\hline 1 and 2 & \multicolumn{2}{|c|}{ Integers: Operation on integers } \\
\hline 3 and 4 & \multicolumn{2}{|c|}{ Integers: Division } \\
\hline 5 and 6 & \multicolumn{2}{|c|}{ Integers: Operation on integers mo } \\
\hline 7 & \multicolumn{2}{|c|}{ Matrices: Subtracting matrices } \\
\hline 8 & \multicolumn{2}{|c|}{ Matrices: Addition of matrices mod } \\
\hline $9-10$ & \multicolumn{2}{|c|}{ Matrices: Multiplication of matrices } \\
\hline 11 & \multicolumn{2}{|c|}{ Matrices: Inverse of a matrix } \\
\hline & Score range & Number of students \\
\hline & $80-100$ & $25(73.6 \%)$ \\
\hline & $75-79$ & $2(5.9 \%)$ \\
\hline & $70-74$ & $5(14.7 \%)$ \\
\hline & $55-59$ & $1(2.9 \%)$ \\
\hline & $45-49$ & $1(2.9 \%)$ \\
\hline
\end{tabular}

TABLE 3 | Scores on mathematical concepts

\begin{tabular}{|c|c|c|}
\hline Mathematical concept & Score range & Number of students \\
\hline Integers: Operation on integers & $80-100$ & 34 \\
\hline Integers: Division & $\begin{array}{l}80-100 \\
65-69\end{array}$ & $\begin{array}{l}32 \\
2\end{array}$ \\
\hline Integers: Operation on integer modulo n & $\begin{array}{l}80-100 \\
65-69 \\
50-55\end{array}$ & $\begin{array}{l}32 \\
1 \\
1\end{array}$ \\
\hline Matrices: Subtracting matrices & $\begin{array}{l}80-100 \\
60-65 \\
0-34\end{array}$ & $\begin{array}{l}31 \\
1 \\
2\end{array}$ \\
\hline Matrices: Addition of matrices modulo n & $\begin{array}{l}80-100 \\
60-65 \\
0-34\end{array}$ & $\begin{array}{l}32 \\
1 \\
1\end{array}$ \\
\hline Matrices: Multiplication of matrices & $\begin{array}{l}80-100 \\
70-75 \\
60-65 \\
50-55 \\
40-45 \\
0-34\end{array}$ & $\begin{array}{l}24 \\
1 \\
2 \\
3 \\
1 \\
3\end{array}$ \\
\hline Matrices: Inverse of a matrix & $\begin{array}{l}80-100 \\
60-65 \\
40-45 \\
0-34\end{array}$ & $\begin{array}{l}16 \\
4 \\
3 \\
11\end{array}$ \\
\hline
\end{tabular}

Copyright (อ) 2020 Samat and Ismail. This is an open-access article distributed under the terms of the Creative Commons Attribution License (CC BY). The use, distribution or reproduction in other forums is permitted, provided the original author(s) and the copyright owner(s) are credited and that the original publication in this journal is cited, in accordance with accepted academic practice. No use, distribution or reproduction is permitted which does not comply with these terms. 